\title{
Complications and Mortality in Systemic Vasculitis - Vasculogenic Clinicopathologic Entities in Rheumatoid Arthritis and Progressive Systemic Sclerosis Autopsy Patients
}

\section{Miklós Bély ${ }^{* 1}$ and Ágnes Apáthy ${ }^{2}$}

${ }^{1}$ Department of Pathology, Hospital of the Order of the Brothers of Saint John of God in Budapest, Hungary

${ }^{2}$ Department of Rheumatology, St. Margaret Clinic Budapest, Hungary

\begin{abstract}
Objective: The aim of this study was to determine: the complication(s) and mortality of systemic vasculitis or vascular changes of autoimmune origin (A-SV) in rheumatoid arthritis (RA) and progressive systemic sclerosis (SSc) patients, and to outline the consecutive complex pathological changes (clinicopathological entities) due to A-SV in various organs.
\end{abstract}

Patients and methods: One hundred sixty one (161) non- selected autopsy patients with RA were studied. This non-selected autopsy population of RA patients was compared with 11 autopsy patients suffering of SSc.

RA and SSc were confirmed clinically according to the criteria of the American College of Rheumatology (ARA).

The basic disease, the complication(s), and the lethal outcome caused by vasculitis were determined and analyzed retrospectively after reviewing the clinical and pathological reports, and confirmed by a study of extensive histological material.

The possible role of A-SV in RA or SSc, specifically in relation to complications and cause of death, furthermore to coexistent associated diseases was analyzed by Pearson's chi-squared $\left(X^{2}\right)$ test.

Results and conclusions: A-SV complicated RA in 33 (20.49\%) of 161 cases. A-SV led directly to death in 19 $(57.57 \%)$ of 33 RA patients, and was present in further $14(42.42 \%)$ of RA patients without a direct role in death. Twenty three of 33 patients died of cardiac, 6 of respiratory insufficiency, and 4 of cachexia, intestinal or renal necrosis. There was a significant and positive correlation between A-SV and multifocal myocardiocytolysis $\left(X^{2}=40.7086, p<0.00001\right)$, or multifocal rheumatoid pneumonia $\left(X^{2}=7.4069, p<0.006\right)$, which were outlined as new vaculogenic entities in $R A$.

SSc was the basic disease leading to death in each of 11 patients, and all of these were complicated by A-SV (with or without fibromuscular intimal proliferation-FIP). Five of 11 SSc patients died of circulatory failure caused by complex cardiomyopathy, with or without honeycomb lung. Complex nephropathy led to uremia in 6 of 11 cases. The significant and positive correlation between FIP and myocardiocytolysis $\left({ }^{2}=4.4818, p<0.034\right)$, or complex nephropathy $\left(x^{2}=5.3047\right.$, $p<0.021)$ indicate that these complications were directly related to A-SV in SSc patients. The abundant interstitial fibrosis in various organs may have been generated by immunological processes independent of vascular changes.

Keywords: Rheumatoid arthritis; Systemic sclerosis; Systemic Vasculitis; Complications; Cause of death

\section{Introduction}

In autoimmune diseases the vascular system is the most important target of immunological processes, manifesting as vasculitis or characteristic structural changes of blood vessels.

Systemic vasculitis of autoimmune origin (A-SV) may be regarded as one of the basic manifestations of rheumatoid arthritis (RA) as well. $\mathrm{A}-\mathrm{SV}$ is one of the main, and the most likely lethal complication to be missed clinically with high probability of RA [1].

The vasculitis and vascular changes are so dominant in progressive systemic sclerosis (SSc) that the disease could be regarded as primary vascular disease. According to Gardner "Evidence of circulatory impairment in systemic sclerosis is so frequent that is natural to ask whether this is fundamentally not a vascular disorder" [2].

The knowledge of complications and associated diseases, furthermore the risk of mortality in various diseases is important in their prevention or earlier and more effective treatment [3]. Studies confirm the increased risk of cardiovascular diseases in RA [4-7]. The cardiovascular complications-beside renal and pulmonary ones - are important in the mortality of SSc patients as well [8-10].

The aim of this study was to determine: the complication(s) and mortality of A-SV in RA and SSc patients, and to outline the consecutive complex pathological changes (clinicopathological entities) due to A-SV in various organs.

\section{Patients (autopsy population)}

At the National Institute of Rheumatology 9475 patients died between 1969 and 1992; among them 161 with RA (females 116, average age: 64.95 years, range $87-16$, onset of RA: 50.19 , average disease duration: 14.79 years; males 45 , average age: 66.29 years, range $88-19$, onset of RA: 52.57 , average disease duration: 13.46 years at death), and all of them were autopsied.

This non-selected autopsy population of RA patients was studied and compared with 11 autopsy patients with SSc (females 10, average age: 53.6 years, range $62-37$, onset of SSc: 43.3 , disease duration: 10.0

*Corresponding author: Miklós Bély, Department of Pathology, Hospital of the Order of the Brothers of Saint John of God in Budapest, Hungary, Tel: (36-1) 3686345; E-mail: dr.bely.miklos@gmail.com

Received April 05, 2017; Accepted April 21, 2017; Published May 05, 2017

Citation: Bély M, Apáthy Á (2017) Complications and Mortality in Systemic Vasculitis - Vasculogenic Clinicopathologic Entities in Rheumatoid Arthritis and Progressive Systemic Sclerosis Autopsy Patients. J Vasc 3: 122. doi:10.4172/2471 9544.1000122

Copyright: (c) 2017 Bély M, et al. This is an open-access article distributed under the terms of the Creative Commons Attribution License, which permits unrestricted use, distribution, and reproduction in any medium, provided the original author and source are credited. 
Citation: Bély M, Apáthy Á (2017) Complications and Mortality in Systemic Vasculitis - Vasculogenic Clinicopathologic Entities in Rheumatoid Arthritis and Progressive Systemic Sclerosis Autopsy Patients. J Vasc 3: 122. doi:10.4172/2471-9544.1000122

Page 2 of 11

years; male 1, age of 65 years, onset of SSc and duration of disease not known).

RA and SSc were confirmed clinically according to the criteria of the American College of Rheumatology (ACR) [11,12].

\section{Methods}

The basic disease, the complication(s), and the lethal outcome caused by vasculitis were determined and analyzed retrospectively, reviewing the clinical and pathological reports, and confirmed by a detailed review of extensive histological material. From each patient 50-100 tissue blocks of 12 organs (heart, lung, liver, spleen, kidneys, pancreas, gastrointestinal tract, adrenal glands, skeletal muscle, peripheral nerve, skin and brain) were studied microscopically [1].

The possible role of A-SV on RA or SSc, specifically in relation to complications and cause of death, furthermore to coexistent associated diseases was analyzed by Pearson's chi-squared $\left(\chi^{2}\right)$ test (the correlations were calculated based on the total number of patients; in case of RA $\mathrm{n}=161$, and SSc $\mathrm{n}=11$ ) [13].

\section{Results}

\section{RA and A-SV}

A-SV complicated RA in 33 (20.49\%) of 161 cases.
RA with A-SV: females 20, average age of 66.95 years, range 82-32, onset of RA: 58.5, disease duration: 10.89 years; males 13 , average age of 67.46 years, range 83-53, onset of RA: 54.69, disease duration: 12.77 years at death.

A-SV led directly to death in 19 (57.57\%) of 33 RA patients: in one case due to coronary arteritis with a large anteroseptal myocardial infarct (MI); in 11 cases coronary arteritis or arteriolitis caused multifocal microinfarcts of the myocardium (myocardiocytolysis-My); in 3 cases vasculitis of the pulmonary and bronchial arterioles and small arteries led to vasculogenic rheumatoid pneumonia with disseminated (multifocal) lobular-sublobular pneumonia (RhPn). In 2 cases cerebral vasculitis with multifocal brain necrosis led to death (in one case due to bronchopneumonia and in the second one due to femoral vein thrombosis, pulmonary embolism and septic infarction of the lung). In one patient thrombovasculitis of the main mesenteric artery caused hemorrhagic necrosis of the intestines; in another case thrombosis of the main renal artery led to renal insufficiency and incipient renal necrosis and was the cause of death.

A-SV was present in further 14 (42.42\%) of 33 RA patients without direct role in death (Table 1).

Twenty three of 33 patients died of cardiac, 6 of respiratoric insufficiency, and 4 of cachexia, intestinal or renal necrosis.

\begin{tabular}{|c|c|c|c|c|c|c|c|c|}
\hline \multicolumn{2}{|c|}{ Basic disease } & \multicolumn{2}{|c|}{ Complication (1-2) } & \multirow{2}{*}{$\begin{array}{l}\text { Cause of death } \\
\text { Myocardiocytolysis, multiple }\end{array}$} & \multirow[t]{2}{*}{$\begin{array}{l}\text { Associated } \\
\text { Disease (s) }\end{array}$} & \multirow{2}{*}{$\begin{array}{l}\mathrm{Cl}+ \\
\mathrm{Cl}- \\
\mathrm{Cl}-\end{array}$} & \multirow{2}{*}{$\begin{array}{c}\begin{array}{c}\text { Severity } \\
\text { of A-SV* }\end{array} \\
0,227\end{array}$} & \multirow{2}{*}{$\begin{array}{c}\text { Pr \# } \\
\text { /year } \\
20 / 70\end{array}$} \\
\hline 1 & RA & A-SV & Coronary arteritis-arteriolitis & & & & & \\
\hline 2 & RA & A-SV & Coronary arteriolitis & Myocardiocytolysis, multiple & Ath & $\mathrm{Cl}-$ & 0,238 & $81 / 70$ \\
\hline 3 & RA & A-SV & $\begin{array}{l}\text { Pulmonary arteritis } \\
\text { Bronchial arteritis }\end{array}$ & Rheumatoid pneumonia & & $\mathrm{Cl}-$ & 0,306 & V/A \\
\hline 4 & RA & A-SV & $\begin{array}{l}\text { Coronary arteritis-arteriolitis } \\
\text { Myocarditis }\end{array}$ & Heart failure & Ath -DM & $\mathrm{Cl}-$ & 0,375 & $114 / 71$ \\
\hline 5 & RA & A-SV & Vasculogenic pancreatitis, multiple & Circulatory failure & $\mathrm{TbF}$ & $\mathrm{Cl}-$ & 0,630 & $174 / 72$ \\
\hline 6 & RA & A-SV & & Cachexia & Ath & $\mathrm{Cl}-$ & 0,313 & $288 / 73$ \\
\hline 7 & RA & A-SV & $\begin{array}{l}\text { Coronary arteritis-arteriolitis } \\
\text { Nodular coronary arteritis } \\
\text { Nodula valvulitis, } \\
\text { Nodular endocarditis } \\
\text { Myocardial rheumatoid nodules } \\
\text { Nodular epicarditis } \\
\text { AA amyloidosis }\end{array}$ & Myocardiocytolysis, multiple & $\mathrm{TbFc-mTb}$ & $\mathrm{Cl}+$ & 0,217 & $395 / 76$ \\
\hline 8 & RA & A-SV & $\begin{array}{l}\text { Coronary arteriolitis } \\
\text { Microinfarction }\end{array}$ & Circulatory failure & Ath -Cirrhosis & $\mathrm{Cl}+$ & 0,100 & $20 / 80$ \\
\hline 9 & RA & A-SV & $\begin{array}{l}\text { Coronary arteritis-arteriolitis } \\
\text { Eosinophilic mycarditis } \\
\text { Cortical necrosis of adrenals }\end{array}$ & Myocardiocytolysis, multiple & & $\mathrm{Cl}+$ & 1,500 & $110 / 80$ \\
\hline 10 & RA & A-SV & & Purulent bronchiolitis & & $\mathrm{Cl}-$ & 0,271 & $175 / 82$ \\
\hline 11 & RA & A-SV & $\begin{array}{l}\text { Pulmonary arteritis } \\
\text { Bronchial arteritis }\end{array}$ & Rheumatoid pneumonia & & $\mathrm{Cl}-$ & 0,153 & $25 / 85$ \\
\hline 12 & RA & A-SV & AA amyloidosis & Uremia & $\mathrm{DM}$ & $\mathrm{Cl}-$ & 0,111 & $43 / 85$ \\
\hline 13 & RA & A-SV & AA amyloidosis & Myocardial necrosis & Ath -DM & $\mathrm{Cl}-$ & 0,069 & $90 / 85$ \\
\hline 14 & RA & A-SV & $\begin{array}{l}\text { Pulmonary arteritis } \\
\text { Bronchial arteritis }\end{array}$ & Rheumatoid pneumonia & Ath & $\mathrm{Cl}-$ & 0,111 & $119 / 85$ \\
\hline 15 & RA & A-SV & $\begin{array}{l}\text { Aortitis } \\
\text { Coronary arteritis-arteriolitis } \\
\text { Pancarditis } \\
\text { Nodula valvulitis, } \\
\text { Nodular endocarditis } \\
\text { Myocarditis } \\
\text { Myocardial rheumatoid nodules } \\
\text { Epicarditis } \\
\text { Vasculogenic pancreatitis, multiple } \\
\text { Vasculitis of intestines }\end{array}$ & Circulatory failure & Ath -TbF & $\mathrm{Cl}-$ & 0,667 & $36 / 86$ \\
\hline
\end{tabular}


Citation: Bély M, Apáthy Á (2017) Complications and Mortality in Systemic Vasculitis - Vasculogenic Clinicopathologic Entities in Rheumatoid Arthritis and Progressive Systemic Sclerosis Autopsy Patients. J Vasc 3: 122. doi:10.4172/2471-9544.1000122

Page 3 of 11

\begin{tabular}{|c|c|c|c|c|c|c|c|c|}
\hline 16 & RA & A-SV & $\begin{array}{l}\text { Cerebral vasculitis, multiple } \\
\text { Brain necrosis, multiple } \\
\text { Deep vein thrombosis } \\
\text { Pulmonary embolism } \\
\text { Glomerulonephritis } \\
\text { Interstitial nephritis }\end{array}$ & Inflammed infarct of the lung & & $\mathrm{Cl}-$ & 0,042 & $123 / 86$ \\
\hline 17 & RA & A-SV & $\begin{array}{l}\text { Coronary arteritis-arteriolitis } \\
\text { Nodular valvulitis } \\
\text { AA amyloidosis }\end{array}$ & Circulatory failure & & $\mathrm{Cl}-$ & 0,292 & $243 / 87$ \\
\hline 18 & RA & A-SV & $\begin{array}{l}\text { Coronary arteritis-arteriolitis } \\
\text { Valvulitis } \\
\text { Endocarditis } \\
\text { Myocarditis }\end{array}$ & Myocardiocytolysis, multiple & & $\mathrm{Cl}+$ & 0,273 & $275 / 87$ \\
\hline 19 & RA & A-SV & $\begin{array}{l}\text { Cerebral vasculitis, multiple } \\
\text { Secondary Sjögren's disease } \\
\text { Thyreoiditis }\end{array}$ & $\begin{array}{l}\text { Brain necrosis, multiple } \\
\text { Bronchopneumonia }\end{array}$ & DM-TbF-CAA & $\mathrm{Cl}-$ & 0,183 & $279 / 87$ \\
\hline 20 & RA & A-SV & $\begin{array}{l}\text { Coronary arteritis-arteriolitis } \\
\text { Nodular valvulitis } \\
\text { Endocarditis } \\
\text { Myocarditis } \\
\text { Myocardial rheumatoid nodules }\end{array}$ & Myocardiocytolysis, multiple & & $\mathrm{Cl}-$ & 0,258 & $312 / 87$ \\
\hline 21 & RA & A-SV & $\begin{array}{l}\text { Thrombovasculitis renal artery } \\
\text { Coronary arteriolitis }\end{array}$ & Renal necrosis & & $\mathrm{Cl}+$ & 0,455 & $194 / 88$ \\
\hline 22 & RA & A-SV & $\begin{array}{l}\text { Coronary arteriolitis } \\
\text { Epicarditis } \\
\text { Vasculitis of intestines } \\
\text { AA amyloidosis }\end{array}$ & Myocardiocytolysis, multiple & TbF-mTb & $\mathrm{Cl}-$ & 0,652 & $240 / 88$ \\
\hline 23 & RA & A-SV & $\begin{array}{l}\text { Coronary arteritis-arteriolitis } \\
\text { Pancarditis } \\
\text { Nodula valvulitis } \\
\text { Nodular endocarditis } \\
\text { Myocarditis } \\
\text { Myocardial rheumatoid nodules } \\
\text { Nodular epicarditis }\end{array}$ & Myocardiocytolysis, multiple & Ath & $\mathrm{Cl}-$ & 0,153 & $295 / 88$ \\
\hline 24 & RA & A-SV & Valvular endocarditis & Heart failure & $\mathrm{DM}$ & $\mathrm{Cl}-$ & 0,042 & $40 / 89$ \\
\hline 25 & RA & A-SV & $\begin{array}{l}\text { Coronary arteriolitis } \\
\text { Acute endocarditis } \\
\text { Myocardial rheumatoid nodules }\end{array}$ & Myocardiocytolysis, multiple & TbFc-mTb & $\mathrm{Cl}-$ & 0,333 & $227 / 89$ \\
\hline 26 & RA & A-SV & $\begin{array}{l}\text { Coronary arteritis-arteriolitis } \\
\text { Nodula valvulitis, } \\
\text { Myocardial rheumatoid nodules } \\
\text { Nodular epicarditis }\end{array}$ & Myocardiocytolysis, multiple & & $\mathrm{Cl}-$ & 0,153 & $285 / 89$ \\
\hline 27 & RA & A-SV & $\begin{array}{l}\text { Aortitis } \\
\text { Coronary arteriolitis } \\
\text { Pancarditis } \\
\text { Nodula valvulitis } \\
\text { Nodular endocarditis } \\
\text { Myocarditis } \\
\text { Myocardial rheumatoid nodules } \\
\text { Nodular epicarditis } \\
\text { Myocardial microinfarctions }\end{array}$ & Circulatory failure & Ath-DM-TbFc & $\mathrm{Cl}-$ & 0,056 & $41 / 90$ \\
\hline 28 & RA & A-SV & $\begin{array}{l}\text { Coronary thrombovasculitis } \\
\text { Coronary arteriolitis }\end{array}$ & Myocardial necrosis & Ath-TbFc-Ca & $\mathrm{Cl}-$ & 0,111 & $65 / 90$ \\
\hline 29 & RA & A-SV & $\begin{array}{l}\text { Coronary arteriolitis } \\
\text { Nodular pancarditis } \\
\text { Nodula valvulitis, } \\
\text { Myocardial rheumatoid nodules } \\
\text { Nodular epicarditis } \\
\text { Myositis }\end{array}$ & Circulatory failure & Ath-TbFc-mTb & $\mathrm{Cl}-$ & 0,083 & $87 / 90$ \\
\hline 30 & RA & A-SV & $\begin{array}{l}\text { Coronary arteriolitis } \\
\text { Pancarditis } \\
\text { Endocarditis } \\
\text { Myocarditis } \\
\text { Epicarditis }\end{array}$ & Circulatory failure & & $\mathrm{Cl}+$ & 0,045 & $146 / 91$ \\
\hline 31 & RA & A-SV & Coronary arteriolitis & Myocardiocytolysis, multiple & & $\mathrm{Cl}-$ & 0,167 & $221 / 91$ \\
\hline 32 & RA & A-SV & $\begin{array}{l}\text { Coronary arteritis } \\
\text { Nodular pancarditis } \\
\text { Nodular pancarditis } \\
\text { Nodula valvulitis, } \\
\text { Myocardial rheumatoid nodules } \\
\text { Nodular epicarditis } \\
\text { Myositis }\end{array}$ & $\begin{array}{l}\text { Circulatory failure } \\
\text { Bronchopneumonia }\end{array}$ & Ath & $\mathrm{Cl}-$ & 0,750 & $14 / 92$ \\
\hline
\end{tabular}


Citation: Bély M, Apáthy Á (2017) Complications and Mortality in Systemic Vasculitis - Vasculogenic Clinicopathologic Entities in Rheumatoid Arthritis and Progressive Systemic Sclerosis Autopsy Patients. J Vasc 3: 122. doi:10.4172/2471-9544.1000122

Page 4 of 11

\begin{tabular}{|l|l|l|l|l}
\hline 33 & RA & SV & $\begin{array}{l}\text { Thrombovasculitis } \\
\text { (Mesenteric artery) }\end{array}$ \\
\hline
\end{tabular}

(Mesenteric artery)

Intestinal necrosis

DM

$\mathrm{Cl}-$

0,083

$144 / 92$

A-SV: - Systemic vasculitis of autoimmune origin (complication with lethal outcome in 19 of 33 patients (bold); complication without fatal outcome in 14 of 33 patients) $\mathrm{Cl}+$ : - Clinically diagnosed systemic vasculitis in $6(18.18 \%)$ of 33 patients (clinically recognized 4 of 19 lethal cases, and 2 of 14 not lethal cases).

Cl-: - Clinically not diagnosed systemic vasculitis in 27 (81.82\%) of 33 patients (clinically not recognized 15 of 19 lethal cases, and 12 of 14 not lethal cases)

Myocardiocytolysis Multiple (multifocal) microinfarction of myocardium (My)

CAA - Cerebral amyloid angiopathy

$\mathrm{Tb}$ - Post-primary (Fc - fibrocaseous, or F - fibrous) tuberculosis

$\mathrm{mTb}$ - active miliary dissemination of $\mathrm{Tb}$

DM - adult type II diabetes mellitus

Table 1: Mortality due to A-SV in RA - (A-SV $n=33$ of 161 , Mortality of A-SV $n=19$ of 33).

The basic disease, complication(s) and associated diseases of $33 \mathrm{RA}$ patients with A-SV are summarized in Glossary to Table 1.

Basic disease: underlying disease related to death.

Complication: consequence of basic disease leading directly to death.

Cause of death (bold): fatal outcome of basic disease.

Associated (Accompanying) disease: Important disorder without direct causal role in death.

Severity of A-SV was determined histologically in one of our previous study [9]:

Atherosclerosis (Ath) -was diagnosed in RA patients only in cases, when it was present macroscopically as a "severe" atherosclerotic process (characterized by occlusive thrombosis or sclerotic ulcers) or,

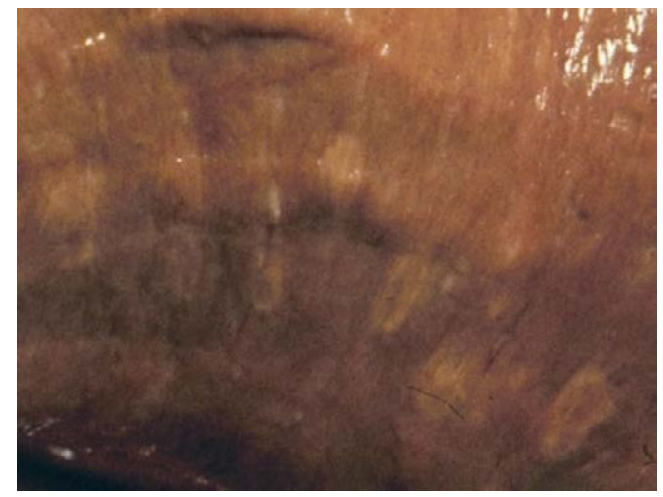

Figure 1: Heart, multiple microinfarts (myocardiocytolysis) of myocardium in different stage of necrosis (Magnification: $\mathrm{x} 4$ ). when it was the basic disease leading to death. Moderate changes like hyaline or sclerotic plaques - without causal role in death - were not mentioned as "atherosclerosis"; such changes are frequent in elderly RA patients.

The most important complications and causes of death or associated diseases in 161 RA patients with or without A-SV are listed bellow:

My complicated RA in 11 (6.83\%) of 161 patients, and all of these were accompanied with A-SV (Figures 1 and 2).

RhPn complicated RA in 3 (1.86\%) of 161 patients, and all of these were accompanied with A-SV (Figure 3).

Bronchopneumonia (BrPn) - partly related to RA, and partly related to Ath - was noted in $22(13.66 \%)$ of 161 patients, and was associated with A-SV in 2 of 22 cases.

AA amyloidosis (AAa) was observed in 34 (21.12\%) of 161 RA patients, and accompanied with A-SV in 5 of 34 patients.

Atherosclerosis (Ath) accompanied RA in 74 (45.9\%) of 161 cases, and was associated with A-SV in 12 of 74 cases.

Cardiac insufficiency (CI - sometimes mentioned as "heart failure", or circulatory failure" - partly related to RA, and partly related to Ath) was registered in 40 (24.84\%) of RA 161 patients, and accompanied with A-SV in 9 of 40 patients.

Myocardial infarction (MI - partly related to RA, and partly related to Ath -was found in 11 (6.83\%) of RA 161 patients, and accompanied with A-SV in 2 of 11 patients.

Adult type II diabetes mellitus (DM) associated to RA in 30 (18.6\%) of 161 patients, and was accompanied with A-SV in 7 of 30 cases.

Post-primary (Fc - fibrocaseous, or F - fibrous) tuberculosis ( $\mathrm{Tb})$ was found in 21 (13.4\%), complicated by active miliary dissemination

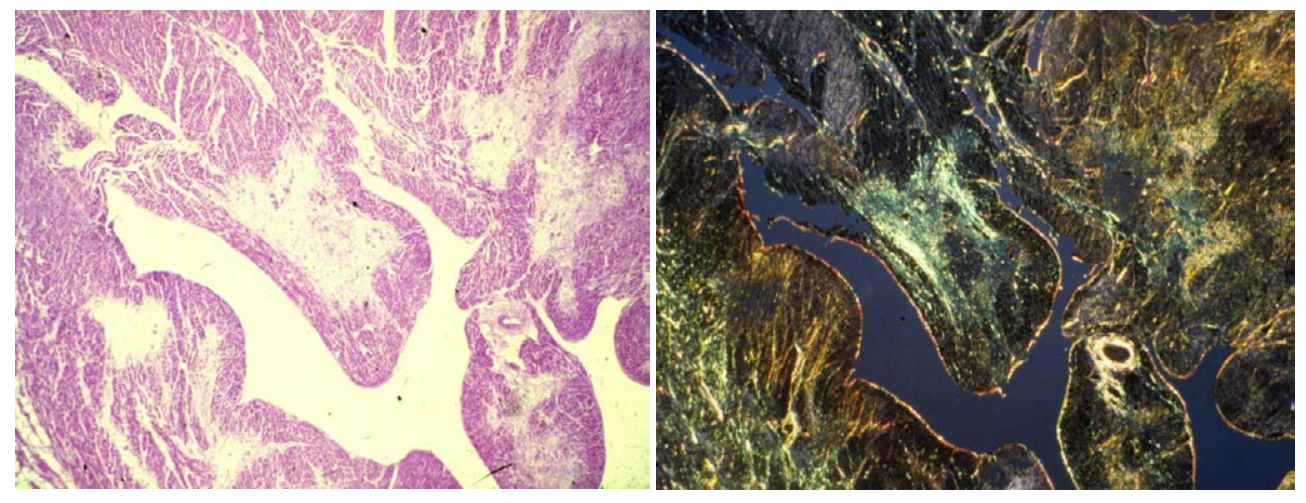

Figure 2: Heart, multiple microinfarcts (myocardiocytolysis) of myocardium in different stages of necrosis

(a) HE, x50 (b) Sirius red F3BA, same as (a) x50. 
Citation: Bély M, Apáthy Á (2017) Complications and Mortality in Systemic Vasculitis - Vasculogenic Clinicopathologic Entities in Rheumatoid Arthritis and Progressive Systemic Sclerosis Autopsy Patients. J Vasc 3: 122. doi:10.4172/2471-9544.1000122

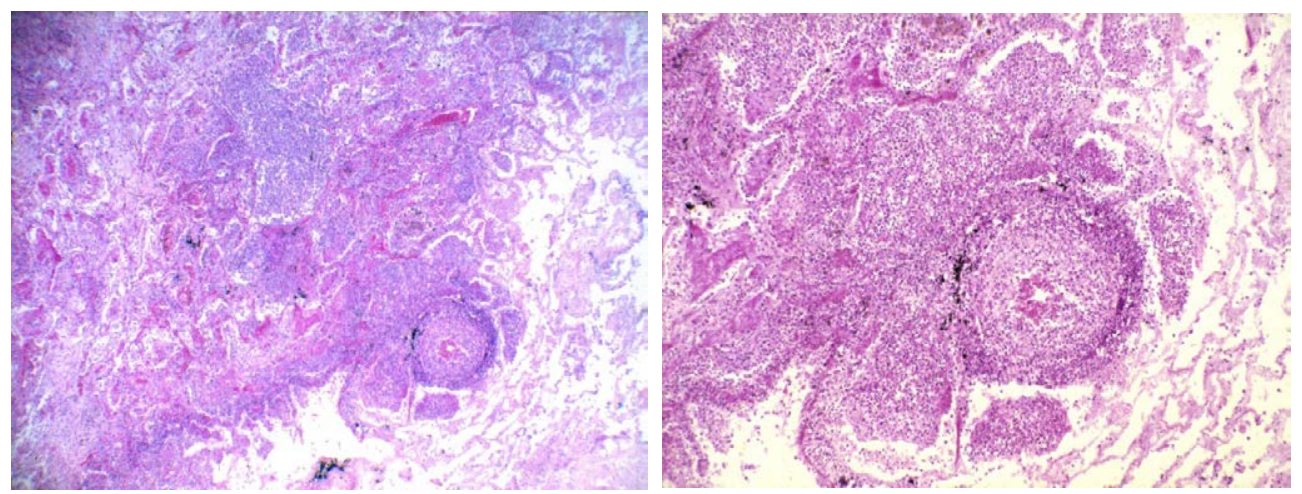

Figure 3: Lung, small bronchial artery, non-specific, acute vasculitis, with sublobular bronchopneumonia

(a) HE, x50 (b) same as (a) x125.

(mTb) in $6(3.73 \%)$ of 161 patients. Tb was associated with A-SV in 9, and active $\mathrm{mTb}$ in 4 of 21 cases.

The statistical link between A-SV and coexistent complications or associated diseases in 161 RA patients is summarized in Table 2.

There was a significant and positive correlationbetween $A-S V$ and prevalence of $M y\left(\chi^{2}=40.7086, \mathrm{p}<0.00001\right)$ between $A-S V$ and prevalence of $\operatorname{RhPn}\left(\chi^{2}=7.4069, \mathrm{p}<0.006\right)$ between $A-S V$ and prevalence of $T b$ $\left(\chi^{2}=7.4096, \mathrm{p}<0.006\right)$, between $A-S V$ and prevalence of $m T b\left(\chi^{2}=5.4751\right.$, $\mathrm{p}<0.019)$.

The correltion between A-SV and $\operatorname{BrPn}\left(\chi^{2}=1.3044, \mathrm{p}<0.253\right)$, AA amyloidosis $\left(\chi^{2}=0.8870, p<0.346\right)$, Ath $\left(\chi^{2}=1.5398, p<0.215\right)$, CI $\left(\chi^{2}=0.6622, \mathrm{p}<0.415\right)$, MI $\left(\chi^{2}=0.036, \mathrm{p}<0.849\right)$, or DM $\chi^{2}=0.1823$, $\mathrm{p}<0.669$ ) was not significant (even in case of $\mathrm{BrPn}, \mathrm{AAa}, \mathrm{Ath}$, and MI - based on the negative association's coefficients the relationships were inverse).

\section{A-SV and SSc}

A-SV and chronic structural changes of blood vessels were present in all of $11 \mathrm{SSc}$ patients.

SSc with A-SV: females 10, average age: 53.6 years, range 62-37, onset of SSc: 43.3 , disease duration: 10.0 years; male 1, age of 65 years, onset of SSc and duration of disease not known.

SSc was the basic disease leading to death in each of 11 patients (Figure 4), and all were complicated by A-SV. Blood vessels of all calibers (arterioles, small arteries and medium size arteries) were involved (capillaries were not evaluated.

A-SV was characterized by a wide spectrum of vascular changes such as non-specific inflammatory infiltration, fibrinoid necrosis, fibromuscular intimal proliferation (FIP), and/or adventitial fibrosis (with or without thrombosis).

Vasculitis and vascular changes were accompanied by a wide spectrum of histological abnormalities in various organs.

In the heart complex vascular changes - FIP $(n=5)$, multifocal myocardiocytolysis or myocardial necrosis $(n=4)$, and/or endomyocardial fibrosis $(n=10)$ was present in 10 of $11 \mathrm{SSc}$ patients. Complex vascular changes - FIP was accompanied by myocardiocytolysis or myocardal necrosis in 4 of 5, and endo-myocardial fibrosis in 5 of 10 cases.

The lungs showed complex vascular changes - FIP $(n=3)$, interstitial

\begin{tabular}{|c|c|c|}
\hline $\begin{array}{l}\text { The prevalence of } \\
\text { complications or } \\
\text { associated diseases }\end{array}$ & $\begin{array}{l}\text { The co-existent } \\
\text { complications or } \\
\text { associated diseases }\end{array}$ & \multirow{3}{*}{$\begin{array}{l}\text { The statistical link (with } \\
\text { association's coefficient } \\
\text { - Ac) between A-SV and } \\
\text { complications or associated } \\
\text { disease in } 161 \text { RA patients }\end{array}$} \\
\hline in $161 \mathrm{RA}$ patients & $\begin{array}{c}\text { in } 33 \text { RA patients with } \\
\text { A-SV }\end{array}$ & \\
\hline with or without A-SV & & \\
\hline Myocardiocytolysis: & Myocardiocytolysis: & Ac: 1 \\
\hline$n=11 / 161$ & $n=11 / 33$ & $x^{\prime \prime}=40.7088, \pi<0.00001$ \\
\hline Rheumtoid pneumonia: & Rheumtoid pneumonia: & Ac: 1 \\
\hline$n=3 / 161$ & $n=3 / 33$ & $X^{\prime \prime}=7.4069, \pi<0.006$ \\
\hline Bronchopneumonia: & Bronchopneumonia: & $A c^{*}:-0.4832$ \\
\hline$n=22 / 161$ & $n=2 / 33$ & $X^{\prime \prime}=1.3044, \pi<0.253$ \\
\hline AA amyloidosis: & AA amyyloidosis: & $A c^{*}:-0.2425$ \\
\hline$n=34 / 161$ & $n=5 / 33$ & $X^{\prime \prime}=0.8870, \pi<0.346$ \\
\hline Atherosclerosis: & Atherosclerosis: & $A c^{*}:-0.2435$ \\
\hline$n=74 / 161$ & $n=12 / 33$ & $X^{\prime \prime}=1.5398, \pi<0.215$ \\
\hline Cardiac insufficiency: & Cardiaac insufficiency: & Ac: 0.1736 \\
\hline$n=40 / 161$ & $n=9 / 33$ & $X^{\prime \prime}=0.6622, \pi<0.415$ \\
\hline Myocardial necrosis: & Myocardial necrosis: & $A c^{*}:-0.0793$ \\
\hline$n=11 / 161$ & $n=2 / 33$ & $x^{\prime \prime}=0.036, \pi<0.849$ \\
\hline Diabetes mellitus: & Diabetes mellitus: & Ac: 0.1027 \\
\hline$n=30 / 161$ & $n=7 / 33$ & $x^{\prime \prime}=0.1823, \pi<0.669$ \\
\hline Tuberculosis: & Tuberculosis: & Ac: 0.5675 \\
\hline$n=21 / 161$ & $n=9 / 33$ & $x^{\prime \prime}=7.4096, \pi<0.006$ \\
\hline mTb: & mTb: & Ac: 0.7935 \\
\hline$n=6 / 161$ & $n=4 / 33$ & $X^{\prime \prime}=5.4751, \pi<0.019$ \\
\hline
\end{tabular}

*Asterisk indicates negative value of association's coefficient (invers relationship between A-SV and complications or associated disease in 161 RA patients). Bold indicates significant value

Table 2: The influence of A-SV on the prevalence of coexistent complications or associated diseases in 161 RA patients.

pneumonitis or fibrosis ( $\mathrm{n}=11$ ), and/or honeycomb-lungs ( $\mathrm{n}=5$ ) (Figure 5) in 11 of SSc 11 patients.

Complex vascular changes FIP was accompanied by interstitial pneumonitis or fibrosis in 3 of 11 , and honeycomb-lungs in 3 of 5 cases.

Complex nephropathy was characterised by complex vascular changes - FIP ( $n=9$ ) (Figure 6), by interstitial nephritis and/or fibrosis $(n=8)$, by mesangiopetroliferative or membranous glomerulonephritis $(n=1)$, and by multifocal cortical necrosis $(n=2)$ in 9 of SSc 11 patients.

FIP was associated to complex nephropathy in all of these 9 SSc patients. 
Citation: Bély M, Apáthy Á (2017) Complications and Mortality in Systemic Vasculitis - Vasculogenic Clinicopathologic Entities in Rheumatoid Arthritis and Progressive Systemic Sclerosis Autopsy Patients. J Vasc 3: 122. doi:10.4172/2471-9544.1000122

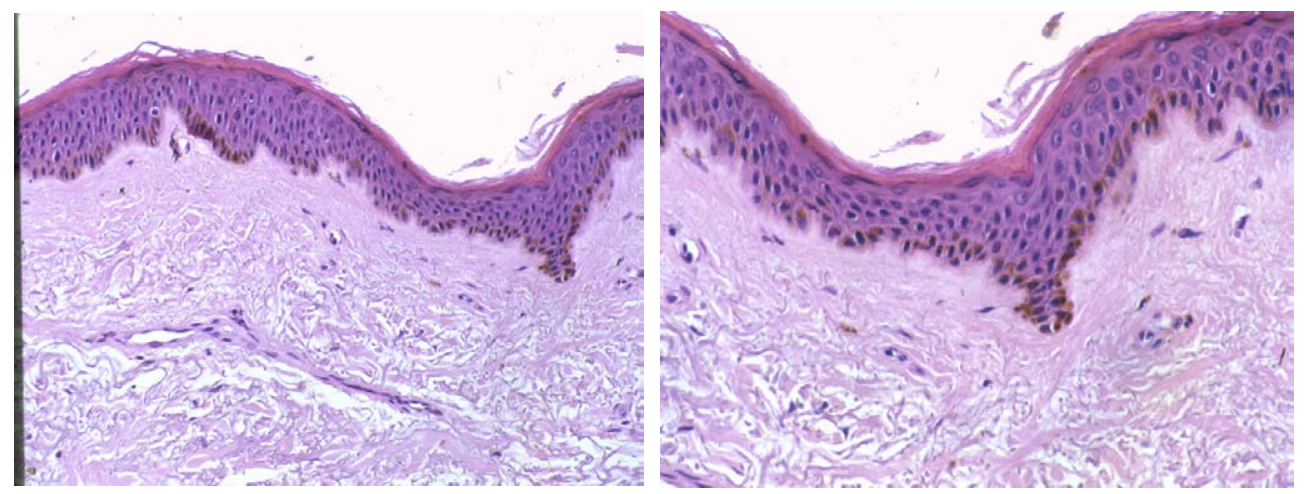

Figure 4: SSc, skin, scleroderma with epidermal atrophy accompanied by slight hyperkeratosisn, and discontinuous hyperpigmentation of the basal layer (a) HE, $\mathrm{x} 50$ (b) same as (a) $\times 125$.
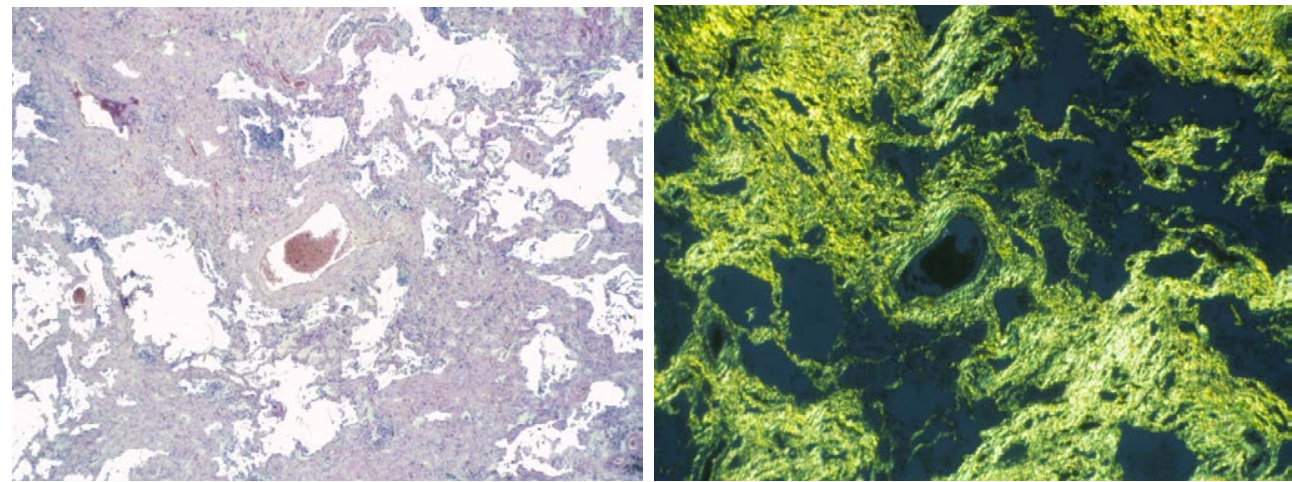

Figure 5: SSc, honeycomb-lung characterized by excessive fibrous tissue, and cystic spaces

(a) HE, x50 (b) Sirius red F3BA, same as (a) x50.
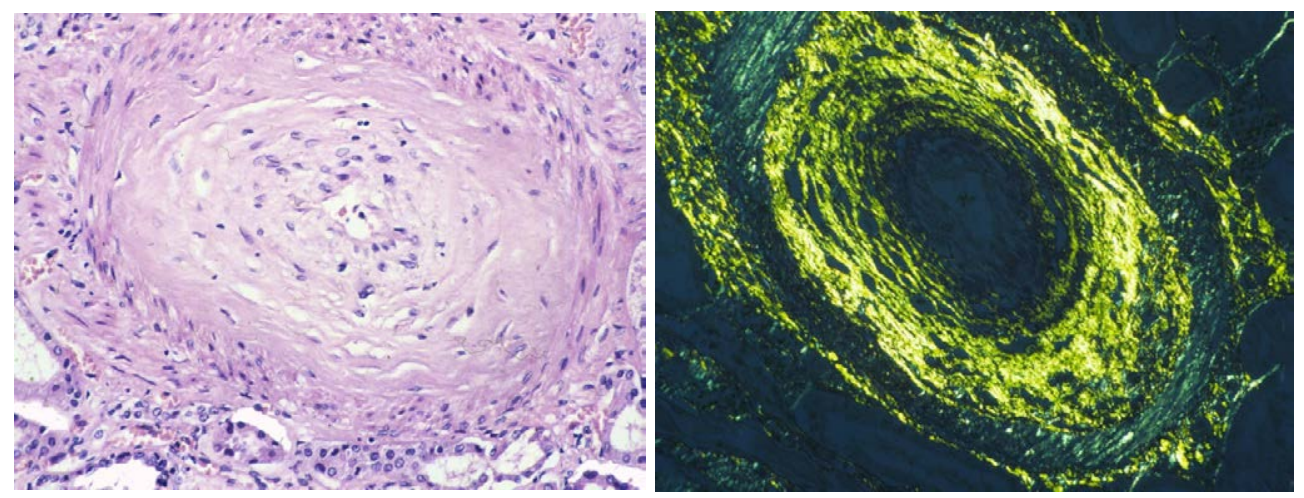

Figure 6: SSc, kidney, small artery, fibromuscular intimal proliferation-FIP and adventitial fibrosis

(a) HE, x125 (b) Sirius red F3BA, same as (a) $\times 125$.

FIP was accompanied by interstitial nephritis in 8 of 9 , by glomerulonephritis in 1 of 1 , by tubular necrosis in 2 of 2 cases.

Five of 11 SSc patients died of circulatory failure caused by histological changes of the heart and lungs. The renal changes led to uremia in 6 of 11 cases.

Associated diseases had, no causal role in death of SSc patient.

The basic disease, complication(s) and associated diseases of 11 SSc patients with A-SV and FIP are summarized in Table 3.
A-SV: Systemic vasculitis of autoimmune origin (complication with lethal outcome in 11 of 11 patients; accompanied with fibromuscular intimal proliferation - FIP in 10 of 11 patients)

Severity of A-SV was determined histologically in one of our previous study: [9]

$\mathrm{Cl}+$ : Clinically recognized "vasculitis" (Ad litteram - "explicit verbis") in 2 (18.18\%) of 11 patients.

Cl-: - Clinically not diagnosed systemic vasculitis in $9(81.82 \%)$ of 11 patients. 
Citation: Bély M, Apáthy Á (2017) Complications and Mortality in Systemic Vasculitis - Vasculogenic Clinicopathologic Entities in Rheumatoid Arthritis and Progressive Systemic Sclerosis Autopsy Patients. J Vasc 3: 122. doi:10.4172/2471-9544.1000122

\begin{tabular}{|c|c|c|c|c|c|c|c|c|}
\hline \multicolumn{2}{|c|}{$\begin{array}{l}\text { Basic } \\
\text { disease }\end{array}$} & \multicolumn{2}{|c|}{ Complications } & \multirow{2}{*}{$\begin{array}{l}\text { Cause of death } \\
\text { Uremia }\end{array}$} & \multirow[t]{2}{*}{$\begin{array}{l}\text { Associated } \\
\text { disease(s) }\end{array}$} & \multirow{2}{*}{$\begin{array}{c}\mathrm{Cl}+\mathrm{Cl}- \\
\mathrm{Cl}-\end{array}$} & \multirow{2}{*}{$\begin{array}{c}\begin{array}{c}\text { Severity } \\
\text { Avg/Pt }\end{array} \\
0,750\end{array}$} & \multirow{2}{*}{$\begin{array}{c}\text { Pr \# /year } \\
\\
44 / 61\end{array}$} \\
\hline 1 & SSc & A-SV & $\begin{array}{l}\text { Complex nephropathy including } \\
\text { FIP } \\
\text { Glomerulonephritis and } \\
\text { Focal tubural necrosis (multiple) } \\
\text { Scleroderma } \\
\text { Multifocal pancreatitis } \\
\text { Gastrointestinal sclerosis } \\
\text { Interstitial pneumonitis } \\
\text { Interstitial fibrosis } \\
\text { Periductal biliary fibrosis }\end{array}$ & & & & & \\
\hline 2 & SSc & A-SV & $\begin{array}{l}\text { Complex nephropathy including } \\
\text { FIP and } \\
\text { Interstitialis nephritis } \\
\text { Honeycomb lung including } \\
\text { Interstitial pneumonitis and } \\
\text { FIP } \\
\text { Scleroderma } \\
\text { Chronic fibrous-fibrinous synovialitis } \\
\text { Multifocal pancreatitis } \\
\text { Myocardial fibrosis }\end{array}$ & Uremia & & $\mathrm{Cl}-$ & 0,690 & $33 / 65$ \\
\hline 3 & SSc & A-SV & $\begin{array}{l}\text { Honeycomb lung including } \\
\text { Interstitial fibrosis and } \\
\text { Peribronchial fibrinoid necrosis (focal) } \\
\text { Fibrous fascitis } \\
\text { Myositis } \\
\text { Scleroderma } \\
\text { Chronic fibrous-fibrinous synovialitis } \\
\text { Complex nephropathy including } \\
\text { FIP and } \\
\text { Interstitialis nephritis } \\
\text { Gastrointestinal sclerosis } \\
\text { Endo-epicardial fibrosis } \\
\text { Periductal biliary fibrosis } \\
\text { Periductal fibrosis of pancreas } \\
\text { Strumitis-Focal interstitial fibrosis }\end{array}$ & $\begin{array}{l}\text { Bronchopneumonia } \\
\text { Circulatory failure }\end{array}$ & & $\mathrm{Cl}-$ & 0,833 & $4 / 83$ \\
\hline 4 & SSc & A-SV & $\begin{array}{l}\text { Complex nephropathy including } \\
\text { FIP and } \\
\text { Interstitialis nephritis } \\
\text { Scleroderma } \\
\text { Chronic endocardial fibrosis } \\
\text { Peri-endoneural fibrosis } \\
\text { Gastrointestinal sclerosis } \\
\text { Chronic fibrous-fibrinous synovialtis } \\
\text { Interstitial fibrosis } \\
\text { Peribronchial fibrosis }\end{array}$ & Uremia & & $\mathrm{Cl}+$ & 1,063 & $35 / 83$ \\
\hline 5 & SSc & A-SV & $\begin{array}{l}\text { Complex nephropathy including } \\
\text { FIP and } \\
\text { Interstitialis nephritis } \\
\text { Interstitial pneumonitis } \\
\text { Scleroderma } \\
\text { Gastrointestinal sclerosis } \\
\text { Multifocal pancreatitis } \\
\text { Chronic fibrous-fibrinous synovialtis } \\
\text { Perineural fibrosis } \\
\text { Endocardial fibrosis } \\
\text { Fibrous fascitis } \\
\text { Periductal biliary fibrosis } \\
\text { Periductal fibrosis of salivary gland }\end{array}$ & Uremia & $\begin{array}{l}\text { Fibrocaseous } \\
\text { tuberculosis }\end{array}$ & $\mathrm{Cl}-$ & 1,056 & $83 / 87$ \\
\hline 6 & SSc & A-SV & $\begin{array}{l}\text { Complex cardiomyopathy including } \\
\text { FIP and } \\
\text { Endo-myocardial fibrosis-Valvulitis } \\
\text { Honeycomb lung including } \\
\text { Interstitial fibrosis and } \\
\text { FIP } \\
\text { Complex nephropathy including } \\
\text { FIP and } \\
\text { Interstitial nephritis } \\
\text { Scleroderma } \\
\text { Gastrointestinal sclerosis } \\
\text { Peri-endoneural fibrosis } \\
\text { Chronic fibrous-fibrinous synovialtis } \\
\text { Periductal fibrosis of pancreas } \\
\text { Struma-Focal interstitial fibrosis } \\
\text { Sclerotising lymphadenopathia }\end{array}$ & Circulatory failure & Meningeom & $\mathrm{Cl}+$ & 1,208 & $35 / 88$ \\
\hline
\end{tabular}


Citation: Bély M, Apáthy Á (2017) Complications and Mortality in Systemic Vasculitis - Vasculogenic Clinicopathologic Entities in Rheumatoid Arthritis and Progressive Systemic Sclerosis Autopsy Patients. J Vasc 3: 122. doi:10.4172/2471-9544.1000122

\begin{tabular}{|c|c|c|c|c|c|c|c|c|}
\hline 7 & SSc & A-SV & $\begin{array}{l}\text { Complex nephropathy including } \\
\text { Chronic recurrent angiopathy - FIP } \\
\text { Interstitial nephritis and } \\
\text { Focal (multiple) tubular necrosis } \\
\text { Multifocal pancreatitis } \\
\text { Periductal fibrosis } \\
\text { Perineural fibrosis } \\
\text { Complex cardiomyopathy including } \\
\text { FIP } \\
\text { Microinfarcts (Myocardiocytolysis) and } \\
\text { Endo-myocardial fibrosis } \\
\text { Chronic fibrous-fibrinous synovialtis } \\
\text { Gastrointestinal sclerosis } \\
\text { Duodenal ulcer } \\
\text { Scleroderma } \\
\text { Interstitial pneumonitis } \\
\text { Peritracheal and peribronchial fibrosis } \\
\text { Peri- and endoneural fibrosis } \\
\text { Myositis } \\
\text { Sjögren-syndrome } \\
\text { Struma-Focal interstitial fibrosis } \\
\text { Periductal biliary lymphoid infiltration } \\
\text { Periductal biliary fibrosis }\end{array}$ & Uremia & & $\mathrm{Cl}-$ & 1,750 & $96 / 88$ \\
\hline 8 & SSc & A-SV & $\begin{array}{l}\text { Interstitialis nephritis } \\
\text { Gastrointestinal sclerosis } \\
\text { Interstitial pneumonitis } \\
\text { Peritracheal-peribronchial fibrosis } \\
\text { Chronic fibrous valvulitis (aorta) } \\
\text { Scleroderma } \\
\text { Fibrous fascitis } \\
\text { Chronic fibrous-fibrinous synovialtis } \\
\text { Perineural fibrosis } \\
\text { Multifocal pancreatitis } \\
\text { Periductal fibrosis of pancreas }\end{array}$ & Uremia & $\begin{array}{l}\text { Actinomycosis } \\
\text { (Tonsilla) }\end{array}$ & $\mathrm{Cl}$ & 0,924 & V/89 \\
\hline 9 & SSc & A-SV & $\begin{array}{l}\text { Honeycomb lung including } \\
\text { Interstitial fibrosis } \\
\text { Complex cardiomyopathy including } \\
\text { FIP } \\
\text { Myocardiocytolysis, } \\
\text { Scarring microinfarcts, } \\
\text { Subacute epicarditis } \\
\text { Fibrous endocarditis-valvulitis } \\
\text { Scleroderma } \\
\text { Sjögren-syndrome } \\
\text { Gastrointestinal sclerosis } \\
\text { Chronic fibrous-fibrinous synovialtis } \\
\text { Peri-endoneural fibrosis } \\
\text { Complex nephropathy } \\
\text { FIP } \\
\text { Interstitial nephritis } \\
\text { Myositis (Interstitial fibrosis) }\end{array}$ & Circulatory failure & & $\mathrm{Cl}-$ & 1,050 & $147 / 97$ \\
\hline 10 & SSc & A-SV & $\begin{array}{l}\text { Complex cardiomyopathy including } \\
\text { FIP of coronary artery } \\
\text { Myocardiocytolysis, } \\
\text { Endo-myocardial fibrosis and } \\
\text { Chronic fibrous valvulitis } \\
\text { Scleroderma } \\
\text { Multifocal pancreatitis } \\
\text { Periductal fibrosis of pancreas } \\
\text { Myositis } \\
\text { Fibrous fascitis } \\
\text { Peri-endoneural fibrosis } \\
\text { Gastrointestinal sclerosis } \\
\text { Interstitial fibrosis (focal) } \\
\text { Sclerosing lymphadenitis }\end{array}$ & Circulatory failure & & $\mathrm{Cl}-$ & 1,030 & $126 / 96$ \\
\hline
\end{tabular}


Citation: Bély M, Apáthy Á (2017) Complications and Mortality in Systemic Vasculitis - Vasculogenic Clinicopathologic Entities in Rheumatoid Arthritis and Progressive Systemic Sclerosis Autopsy Patients. J Vasc 3: 122. doi:10.4172/2471-9544.1000122

\begin{tabular}{|c|c|c|c|c|c|c|c|}
\hline 11 & SSc & A-SV & $\begin{array}{l}\text { Complex cardiomyopathy including } \\
\text { FIP of coronary artery } \\
\text { Myocardial necrosis } \\
\text { Circumscript endocardial fibrosis and } \\
\text { Interstitial myocardial fibrosis } \\
\text { Scleroderma } \\
\text { Gastrointestinal sclerosis } \\
\text { Honeycomb lung (focal) including } \\
\text { Interstitial pneumonitis } \\
\text { FIP and } \\
\text { Circuscript pleural fibrosis } \\
\text { Complex nephropathy including } \\
\text { Chronic renal angiopathie -FIP and } \\
\text { Interstitial nephritis } \\
\text { Peri-endoneural fibrosis } \\
\text { Chronic fibrous fascitis } \\
\text { Myositis } \\
\text { Sclerotising lymphadenitis } \\
\text { Systemic AA amyloidosis }\end{array}$ & Heart failure & $\mathrm{Cl}-$ & 2,063 & $196 / 97$ \\
\hline
\end{tabular}

Table 3: Mortality due to A-SV in SSc-(A-SV $n=11$ of 11 , complicated by FIP $n=10$ of 11).

All of 11 SSc patients were complicated with A-SV; and FIP was present in 10 of $11 \mathrm{~A}-\mathrm{SV}$ cases.

The statistical link between FIP and coexistent complications in 11 SSc patients is summarized in Table 4 .

Ac: association's coefficient

\section{Bold indicates significant value}

There was a significant and positive correlationbetween FIP and prevalence of $M y$ or myocardial necrosis $\left(\chi^{2}=4.4818, \mathrm{p}<0.034\right)$ between FIP and prevalence of complex nephropathy $\left(\chi^{2}=5.3047, \mathrm{p}<0.021\right)$. In our patients the correltion between FIP and interstitial pneumoniitis and/or interstitial fibrosis $\left({ }^{2}=0.3636, \mathrm{p}<0.546\right)$, honeycomb-lung $\left(\chi^{2}=2.3871\right.$, $\mathrm{p}<0.122)$, interstitial nephritis $\left(\chi^{2}=0.0763, \mathrm{p}<0.7825\right)$, tubular necrosis $\left(\chi^{2}=0.0763, \mathrm{p}<0.7825\right)$, or glomerulonephritis $\left(\chi^{2}=0.7486, \mathrm{p}<0.386\right)$ was not significant.

\section{Discussion}

Vasculitis or vascular changes of autoimmune origin are among the most important complications of RA or SSc, and are considered a direct consequence of the basic diseases.

The explicit extra-articular manifestation of A-SV, and extensive involvement of the cardiovascular, respiratory, urinary, and alimentary system in RA [14-16], or SSc [17-19] support and explain our data of mortality caused by A-SV of autoimmune origin.

\section{Comments to A-SV in RA}

In our study RA and A-SV, with or without other complications (AA amyloidosis) or associated diseases (atherosclerosis, etc,), led to death by cardiac insufficiency in 23 (multifocal microinfarction of myocardium - My $\mathrm{n}=11$, large myocardial necrosis $\mathrm{n}=2$, by heart failure or circulatory failure $\mathrm{n}=10$ ), and due to respiratory insufficiency in 6 (rheumatoid pneumonia $\operatorname{RhPn} \mathrm{n}=3$, bronchopneumonia $\mathrm{n}=2$, infarct pneumonia $\mathrm{n}=1$ ) of 33 cases. Four of 33 patients died of cachexia, intestinal or renal necrosis).

My or RhPn are regarded as direct consequences of A-SV, supported by the significant and very strong positive correlation between them, and may outline them as new vasculogenic entities in RA.

\section{Summarized formal pathogenesis of multifocal microinfarction of myocardium in RA}

Vasculitis distal to the involved vessels can cause local ischemia and regressive (necrobiotic) changes.

\begin{tabular}{|c|c|c|}
\hline $\begin{array}{l}\text { The prevalence of } \\
\text { histological changes }\end{array}$ & Co-existence of FIP & \multirow{3}{*}{$\begin{array}{l}\text { The statistical link (with } \\
\text { association's coefficient } \\
\text { - Ac) between FIP and } \\
\text { histological changes in } 11 \\
\text { SSc patients }\end{array}$} \\
\hline in various organs & in various organs & \\
\hline of 11 SSc patients & of 11 SSc patients & \\
\hline \multirow{2}{*}{$\begin{array}{l}\text { Endomyocardial fibrosis: } \\
\qquad n=10 / 11\end{array}$} & accompanied by FIP: & Ac: 0.9166 \\
\hline & $n=5 / 10$ & $X^{\prime \prime}=0.0091, \pi<0.9237$ \\
\hline $\begin{array}{l}\text { Myocardiocytolysis or } \\
\text { myocardial necrosis: }\end{array}$ & accompanied by FIP: & Ac: 1 \\
\hline$n=4 / 11$ & $\mathrm{n}=4 / 4$ & $x^{\prime \prime}=4.4818, \pi<0.034$ \\
\hline $\begin{array}{l}\text { Interstitial pneumonitis } \\
\text { and/or fibrosis: }\end{array}$ & accompanied by FIP: & Ac: 1 \\
\hline$n=11 / 11$ & $n=3 / 11$ & $x^{\prime \prime}=0.3636, \pi<0.546$ \\
\hline Honeycomb-lung: & accompanied by FIP: & Ac: 1 \\
\hline$n=5 / 11$ & $n=3 / 5$ & $X^{\prime \prime}=2.3871, \pi<0.122$ \\
\hline Complex nephropathy: & accompanied by FIP: & Ac: 1 \\
\hline $\mathrm{n}=9 / 11$ & $\mathrm{n}=9 / 9$ & $X^{\prime \prime}=5.3047, \pi<0.021$ \\
\hline Interstitial nephritis: & accompanied by FIP: & Ac: 0.7777 \\
\hline$n=9 / 11$ & $\mathrm{n}=8 / 9$ & $X^{\prime \prime}=0.0763, \pi<0.7825$ \\
\hline Tubular necrosis: & accompanied by FIP: & Ac: 1 \\
\hline$n=2 / 11$ & $\mathrm{n}=2 / 2$ & $x^{\prime \prime}=0.0763, \pi<0.7825$ \\
\hline Glomerulonephritis: & accompanied by FIP: & Ac: 1 \\
\hline$n=1 / 11$ & $\mathrm{n}=1 / 1$ & $X^{\prime \prime}=0.7486, \pi<0.386$ \\
\hline
\end{tabular}

Ac: association's coefficient

Bold indicates significant value

Table 4: The influence of FIP on the prevalence of coexistent complications in 11 SSc patients.

This process is more or less widespread and multifocal, depending on the number of involved vessels, i.e. on the severity of vasculitis.

The size of necrobiotic areas depends on the size of involved vessels. Vasculitis of the main coronary arteries with or without thrombosis may result in ischemia and may lead to a large myocardial infarct, macroscopically similar to myocardial necrosis due to coronary atherosclerosis and/or thrombosis. Vasculitis of the small arteries and arterioles causes small necrotic foci, 1-2 $\mathrm{mm}$ of diameter (Figure 1).

The immunological processes in RA are recurrent events, and all types of autoimmune vasculitis are of a relapsing nature. Histologically different (acute -subacute-subchronic-chronic) stages of inflammation can be found simultaneously side by side in the same or in different vessels, reflecting the repeated process of vasculitis.

Repeated (recurring) ischemic attacks will be followed by small foci of myocardial necrosis in different stages of necrobiosis. 
Citation: Bély M, Apáthy Á (2017) Complications and Mortality in Systemic Vasculitis - Vasculogenic Clinicopathologic Entities in Rheumatoid Arthritis and Progressive Systemic Sclerosis Autopsy Patients. J Vasc 3: 122. doi:10.4172/2471-9544.1000122

Page 10 of 11

Homogeneous necrotic areas alternating with small lytic foci of myocardium (myocardiocytolysis) and scars of a similar size are existing simultaneously side by side (Figure 2).

Because of the recurrent nature of autoimmune vasculitis the regressive changes accumulate in the myocardium with time and may lead to unexpected sudden death [20].

It is difficult $\mathbf{b} d$ inically $\mathbf{e}$ cognize small accumulating $6 \mathrm{ci}$ of myocardial necrosis (myocardiocytolysis). The history of vasculitis, transient cardiac complaints, low voltage electrocardiogram (ECG) may help in the diagnosis [20].

\section{Summarized formal pathogenesis of rheumatoid pneumonia (vasculogenic disseminated (multifocal) lobular-sublobular pneumonia) in RA}

Severe necrotizing vasculitis, with or without thrombosis plays a major role in the pathogenesis of vasculogenic or so-called rheumatoid pneumonia (RhPn). Diminished blood supply due to vasculitis distal to the involved vessels may result in ischemia and vulnerable territories (loci minoris resistentiae) for a secondary infection (via bronchogenic or hematogenic route) (Figure 3). According to the size of involved vessels lobular or sublobular pneumonia may develop (usually less than 10-20 millimeters in diameter), more or less respecting the anatomic borders of pulmonary units. The inflammation does not have a he morrhagic character, in contrast to infarct-pneumonia due to thrombovasculitis with simultaneous venous congestion. Vasculogenic RhPn differs from bronchopneumonia as well, which is bronchocentric, has no sharply demarcated borders and is independent of the fine a natomic borders of the lung.

Any forms of autoimmune vasculitis are of a relapsing (recurrent) nature, leading to the silent accumulation of inflammatory foci side by side in different stages of inflammation. The number of inflammatory foci (severity RhPn) depends on the number of involved vessels and on the frequency of repeated exacerbation of vasculitis [21].

Clinically it is difficult to recognize the small (silently accumulating) inflammatory f oci in t he l ungs. The hi story of va sculitis, tr ansient pulmonary complaints with or without fever may help in the diagnosis. In case of multifocal, transient (migratory) pneumonia which is refractory to antibiotics, RhPn should be considered [21].

The lack of s ignificant (e ven in verse) co rrelation be tween A- SV and bronchopneumonia, AA amyloidosis, atherosclerosis, cardiac insufficiency, my ocardial ne crosis, $\alpha$ adult ty pe II diabetes mellitus show, that these complications or associated diseases are more or less independent of A-SV.

The significant a d p sitive correlation $b$ tween A SV $\mathbf{a} d$ tuberculosis or miliary tuberculosis means a positive influence of A-SV (or its therapy with immunosuppressive drugs, or anti-TNF alpha treatment) on prevalence of tuberculosis with or without active miliary dissemination in RA. The presence of A-SV increases the risk of tuberculosis, and endogenous exacerbation and miliary dissemination of tuberculosis [1].

\section{Comments to A-SV in SSc}

In SSc patients A-SV with or without FIP led to death by uremia in 6 , by cardiac insufficiency in 4 , and by respiratory insufficiency in 1 (honeycomb-lung and bronchopneumonia) of 11 cases.

There was a strong positive (significant) correlation be tween FIP and complex nephropathy $\left(\chi^{2}=5.3047, \mathrm{p}<0.021\right)$, or myocardiocytolysis and/or myocardial necrosis $\left(\chi^{2}=4.4818, \mathrm{p}<0.034\right)$. Our data support the thesis that SSc could be regarded as a primary vascular disease [2,22].

We did not find significant correlation between FIP and interstitial inflammation or fibrosis. The lack of significant correlation between FIP and endo-myocardial fibrosis, pneumonitis-pulmonary fibrosis, interstitial nephritis, glomerulonephritis, tubular necrosis may be explained by the small number of cases.

The pathogenic role of capillaries and capillary changes (could) should not be ruled out in these interstitial histological changes of the heart, lungs or kidneys (capillaries with very characteristic electronmicroscopic changes were not evaluated in this study).

"There is intense interest in the possibility that dermal fibroblasts may synthesize excess and/or abnormal collagen and proteoglycan, partly for genetic reasons, but partly in response to local abnormalities of the circulation" [23].

The progressive sclerosis in various organs of SSc patients may be the result of direct qualitative changes in the interstitial collagen fibres, generated by extravascular immunological processes independent of vascular changes. Previous studies support this possibility as well [24-26].

\section{Conclusion}

Interactions of coexisting complications in RA or SSc modify the basic disease as well as the typical clinical manifestations of the complications. These changes may lead to misdiagnosis or late recognition of the complications.

The coexisting associated diseases may mask the characteristic clinical symptoms of RA or SSc and may lead to an incorrect diagnosis or late recognition of basic diseases or on the contrary even the recognition of associated diseases may be delayed.

Knowledge of formal pathogenesis of new clinical pathological entities is important from the viewpoint of prevention and effective treatment of these.

Detailed histological evaluation - based on a large autopsy population of RA and SSc patients in one institution may support or statistically confirm theories (for example Gardner's concept [23]) regarding the determination of excessive interstitial fibrosis in SSc patients.

Our recommendation is to look for minor symptoms of modified complications and associated diseases; knowing of these possibilities ("we see what we know") may help in treatment or prevention.

\section{References}

1. Bély M, Apáthy Ágnes (2012)“Systemic vasculitis in rheumatoid arthritis" In Clinical pathology of rheumatoid arthritis: Cause of death, lethal complications and associated diseases in rheumatoid arthritis. J Clin Trial Cardiol 2: 1-9

2. Gardner DL (1992) "Sytemic sclerosis and allied disorders" In Pathological basis of the connective tissue diseases. Indian J Rheumatol 17: 706.

3. Kelly C, Hamilton J (2007) What kills patients with rheumatoid arthritis? Rheumatology (Oxford) 46: 183-184.

4. Goodson NJ, Wiles NJ, Lunt M, Barrett EM, Silman AJ, et al. (2002) Mortality in early inflammatory polyarthritis: cardiovascular mortality is increased in seropositive patients. Arthritis Rheum 46: 2010-2019.

5. Hall FC, Dalbeth $N$ (2005) Disease modification and cardiovascular risk reduction: two sides of the same coin? Rheumatology (Oxford) 44: 1473-1482.

6. Kaplan MJ (2006) Cardiovascular disease in rheumatoid arthritis. Curr Opin Rheumatol 18: 289-297. 
Citation: Bély M, Apáthy Á (2017) Complications and Mortality in Systemic Vasculitis - Vasculogenic Clinicopathologic Entities in Rheumatoid Arthritis and Progressive Systemic Sclerosis Autopsy Patients. J Vasc 3: 122. doi:10.4172/2471-9544.1000122

7. Charles-Schoeman C (2012) Cardiovascular disease and rheumatoid arthritis: an update. Curr Rheumatol Rep 14: 455-462.

8. Steen VD, Medsger TA (2007) Changes in causes of death in systemic sclerosis, 1972-2002. Ann Rheum Dis 66: 940-944.

9. Meune C, Vignaux O, Kahan A, Allanore Y (2010) Heart involvement in systemic sclerosis: evolving concept and diagnostic methodologies. See comment in PubMed Commons below Arch Cardiovasc Dis 103: 46-52.

10. Kahan A, Coghlan G, McLaughlin V (2009) Cardiac complications of systemic sclerosis. Rheumatology (Oxford) 48: 45-48.

11. Arnett FC, Edworthy SM, Bloch DA, McShane DJ, Fries JF, et al. (1988) The American Rheumatism Association 1987 revised criteria for the classification of rheumatoid arthritis. Arthritis Rheum 31: 315-324.

12. van den Hoogen F, Khanna D, Fransen J, Johnson SR, Baron M, et al. (2013) Classification criteria for systemic sclerosis: an American college of rheumatology/European league against rheumatism collaborative initiative. Ann Rheum Dis $72: 1747-55$.

13. Lentner C (1982) "Statistical methods" In Geigy scientific tables. Int J Qual Health Care 5: 372-373.

14. Gardner DL (2015) "Sytemic sclerosis and allied disorders" In Pathological basis of the connective tissue diseases. Int J Qual Health Care 12: 489-503.

15. Fassbender HG (2002) "Rheumatoid arthritis" in Pathology and pathobiology of rheumatic diseases. J Clin Trial Cardiol 2: 159-160.

16. Mohr W (2000) Chronische Gelenkentzündungen,“ In Gelenkpathologie, historische Grundlagen, Ursachen und Entwicklungen von Gelenkleiden und ihre Pathomorphologie 17: 334-335.
17. Gardner DL (1992) "Systemic sclerosis and allied disorders" In Pathological basis of the connective tissue diseases. 17: 700-704.

18. Fassbender HG (2002) "Systemic sclerosis" in Pathology and pathobiology of rheumatic diseases 10 10.3 265-270.

19. Mohr W (2000) Chronische Gelenkentzündungen,“ In Gelenkpathologie, historische Grundlagen, Ursachen und Entwicklungen von Gelenkleiden und ihre Pathomorphologie, 1st ed.: Springer-Verlag, Berlin, Heidelberg, Germany, 363-366.

20. Bély M, Apáthy Á (2006) Pathogenesis Silent Myocardial Infarction in Rheumatoid Arthritis - A Retrospective Clinicopathologic - Statistical Study of 234 Autopsy Patients Ann Rheum Dis 65 164-165.

21. Bély M, Apáthy Á (2013) Rheumatoid arthritis with multifocal migratory vasculogenic pneumonia refractory to antibiotics. Ann Rheum Dis 71: 176

22. Jayson MI (1983) Systemic sclerosis--a microvascular disorder? J R Soc Med 76: $635-642$

23. Gardner DL (1992) "Sytemic sclerosis and allied disorders" In Pathologica basis of the connective tissue diseases. 707

24. Ištok R, Bély M, Stancíková M, Svik K, Rovenský J (1999) Pyridinoline in fibrotized tissues of patients with systemic sclerosis. Ann Rheum Dis 58: 192.

25. Ištok R, Bély M, Stancíková M, Rovenský J (2000) Pyridinoline cross-link in fibrotic tissue in patients with SSc. Reumatologia 2: 91.

26. Ištok R, Bély M, Stancíková M, Rovenský J (2001) Evidence for increased pyridinoline concentration in fibrotic tissues in diffuse systemic sclerosis. Clin Exp Derm 26: 545-547. 